\title{
EDUCATIONAL SERVICES IN NARRATIVE MUSEUM TAKING AS AN EXAMPLE BASTEJA, THE HISTORICAL MUSEUM IN STARGARD
}

\section{PAULINA DĄBROSZ-DREWNOWSKA}

University of Szczecin, Faculty of Management and Economics of Services, POLAND

e-mail: paulina.dabrosz-drewnowska@wzieu.pl

\begin{abstract}
RECEIVED
6 November 2018

ACCEPTED

3 December 2018

JEL

CLASSIFICATION

A12, M14

KEYWORDS

narrative museum, historical museum, Basteja, services, educational services

ABSTRACT The aim of the article is the analysis of the educational services provided by a museum taking as an example the historical museum Basteja in Stargard, in Poland (West Pomeranian Region). This institution could be considered exemplary for the new type of modern museum - the narrative museum. It is situated in one of the lesser towns of Poland. The article enumerates the main educational services, focusing on historical ones. It tells how it is important to build local social awareness and to instill the historical knowledge especially to the young generation living in the small communities.
\end{abstract}

\section{Introduction}

The museums are the institutions representing the Polish culture. Their goal is at first gathering and the continuous protection of natural and cultural goods of the common heritage of mankind, at the same time material and intangible. Secondly, they serve to inform about the value and the nature of stocked collections, to popularize 
the essential of Polish and worldwide history, science and culture, to form the cognitive and esthetic sensibility and to facilitate the use of the gathered collections (Ustawa z 29 czerwca...).

The XXI century and the social transformations bring the changes in the functioning of the museums. The museum as the public institution become nowadays the service providers for the citizens as part of the informative society where the information is a product and the area of services is strongly developed. The narrative museum is a particular type of a museum up against the challenges of the informative revolution undergoing during the last few years, fitting perfectly the concept of the museum and its tasks merging in the XXI century.

The narrative museum relates the past not only by means of the museum objects but also using the words, images and music. It creates the illusion of the past reality and it invites the visitors to get familiarized with it. A part from presenting the objects (exhibitions), it is concentrating more and more on education (Machałek, 2016, p. 133).

Not only the protection (collections of the museum objects, systematization and sorting) is primordial today. The esthetic function takes it place which is understood as sensitization to beauty. The museum proposes more and more the educational services. It relates to the education of specific social groups belonging to different teaching institutions but also outside them.

The specific character of any educational service results from two fundamental elements which are : the process of education which is essential for that service is realized in defined time and its results, understood as achievement of certain level of knowledge and abilities could be observed after all the process (ex ante) (Stecyk, 2016, p. 43).

The historical museum plays an important role in spreading of the historical knowledge. The growing popularity of the history not only in Poland but also in the whole world results from the growth of the conscience that the knowledge of the past constitute a cultural and intellectual asset of people's education and it should be protected (Machałek, 2016, p. 133).

The possibilities of providing the educational services by the museums become wider thanks to the restructuration of the museum institutions today, new technologies in use influence the way of presenting the collections and the visits. The traditional museum interacts with its visitors. Thanks to this dialogue, museums in smaller communities increase their chances to attract the locals with their history and culture and at the same time build their identity.

Basteja, the historical museum in Stargard (Pomeranian region) can serve as a perfect example of narrative museum created in minor community.

\section{Contemporary challenges for museums and the tasks of narpative museums}

The rapid changes in science as well as the development of modern communicative and informative technologies caused the increase of demands towards museums. The alternations englobe in first place the big cities but they touches as well the local museums. Today, the contemporary tools as multimedia and internet are in common use. The visitor awaits innovation in a way of transmitting the knowledge. Museums have changed their attitude towards the public, who are no longer treated as a necessary evil which had to be let into the temple intended for storing and protecting works of art. Museums have recognized their public as desirable visitors for whom a lot of people are working (Kosiewski, 2015, p. 41).

The commercialization of the culture and the blossoming of the massive culture has taken place recently. It invaded the area of high culture (Rottermund, 2005, p. 13). Due to this fact, the museums had to change their 
way of functioning and to adjust to the marketing rules. They started to examine the needs of the visitors and seek ways to attract them to show their museum collections as unique and authentic objects and more efficiently teach our history (Rottermund, 2005, p. 14). Regarding all these elements, contemporary museums have more job to interest their clients. In result, the museum started to propose the various offers and it became a natural museum practice nowadays. It became beneficial particularly when the cultural institutions in Poland are underfunded or the grants applied are poor. All those activities require funds (receipts). The visitor today is no more a passive receptor who is concentrated on seeing the museum objects. He wants to actively interact with what is being shown. The narrative museum is responding to that visitor perfectly where a word, image and music take their part in education (Machałek, 2016, p. 133). Other examples of this type pf museum are The Warsaw Rising Museum and POLIN Museum of the History of Polish Jews in Warsaw and Center for Dialogue Breakthrough (department of the National Museum in Szczecin).

The museums are the educative centers offering a vast choice of educational services. ${ }^{1}$ They adapt existing buildings or build new areas to be able to offer the new type exhibitions which become more at disposal with new multimedia and mobile technics solutions. The narrative museum is constructed basing on the multisensory method which facilitate the acquisition of the new knowledge more proficiently (Machałek, 2016, p. 135). The interactive exhibitions are attractive for the young visitors. The narrative exhibitions impact on their intellect as well as the emotions making them dialogue, think, ask questions and find answers. The other senses like vision, audition, olfaction and touch are also involved. All those elements create an unforgettable museum experience. The narrative museum based on multimedia is considered as the future of all museums (Ziółkowska-Weiss, 2013, p. 167).

In this type of museum, the new role of educators emerge. They show the exhibition and make the visitors interact with history. The possibilities of knowledge transmission are more diverse than in traditional museum. The museum become the service provider in the whole educational process disposing of a qualified human asset (the museum employees like museum educators), the infrastructure and technics necessary to provide educational services. The clients (people receiving the service/educational services) are the individuals under education and those who participate in the process who aim at the effect of that process. The public subject is charged with the costs of the service and in some cases (the services paid) it's the stakeholders who are charged with the part of costs. Among the tools used currently in museums, there are interactive touch screens, multimedia presentations and theater plays, interactive games, laser show projectors, 3D films, visualizations and holograms.

This type of museum is very important for children and young people for its education of history. In Poland, they are mostly in big cities and they are not common in towns but once there, they play a crucial role for local communities, situated far from metropolitan areas. In the article, the case study method was of use.

\section{Basteja - the historical museum in Staryard}

Stargard is a town located in Pomeranian region and it's one of the oldest burghs. It's called the "treasure of Pomeranian region" because of the well- preserved monuments. Stargard has around 70000 inhabitants. The town was built between the age VIII and IX. Stargard was a member of Hanza. There are lots of vestiges of that time still in the town like the Collegiate of Holy Virgin Mary dating from XIII and XIV. The monuments are listed in the

${ }^{1}$ There are educational programs, archives of oral history, scientific studies, theater plays, discussions, concerts film shows, professional websites created in those institutions. 
European Route of Brick Gothic which presents the heritage of brick gothic architecture in towns located at the Baltic Sea. The members are 34 towns from seven countries like Denmark, Estonia, Lithuania, Latvia, Germany, Poland and Sweden and from 19 july 2006 also the town Stargard (Stargard..., 2018). The route of gothic brick offers the fascinating world of gothic, legends, interesting historical facts and the beautiful landscapes.

In the offer of the museum, there are music lessons for children and youngsters, vacation classes, kinder parties, history courses, scientific conferences, games and escape room, meetings of history, art and culture amateurs (Muzeum archeologiczno-historyczne Stargard, 2018).

Basteja is part of Stargard Historical and Archeological Museum (self-governmental institution in Stargard) and it gathers archeological, archival, ethnographical, photographical, military and numismatic collections (Photos 1-2). Basteja was created at the beginning of XVI century as a part of fortifications. ${ }^{2}$ After the demolition in 1945 , it was restored in the years 1979-1980 and passed in hands of Stargard Museum. In 2013, ${ }^{3}$ Basteja was renovated, enlarged and adjusted to the needs of new type exhibitions. Stargard - place full of history from medieval ages to the 20's of XX century is one of those new type permanents exhibitions. A part from museum objects, there are numerous computer screens, touch screens and other multimedia. Bilingual exhibition with audio description is at disposal (Polish, German and partially English) for disabled people (Historia..., 2018).

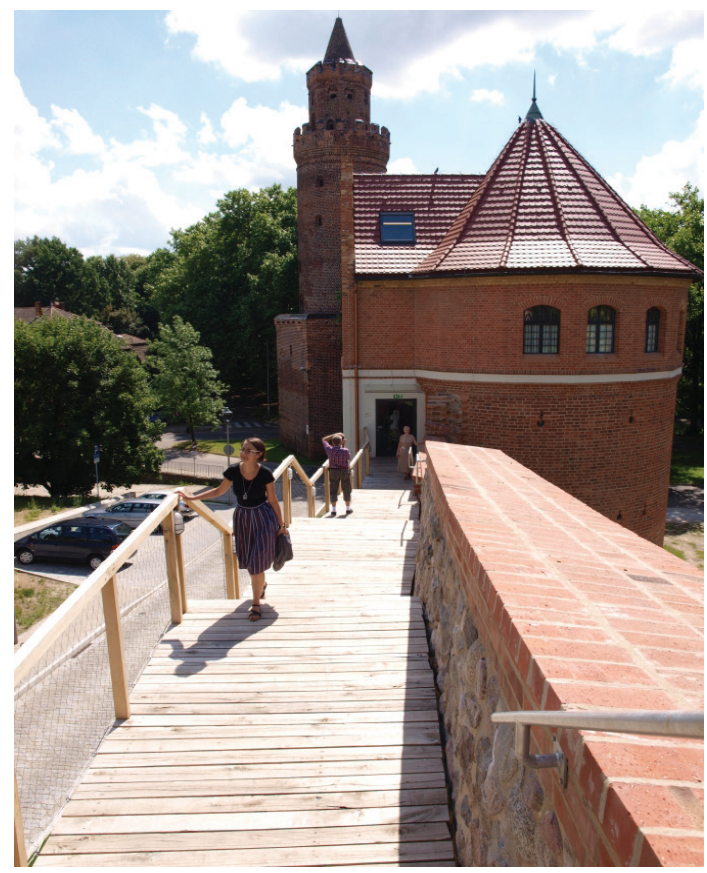

Photo 1. Basteja

Source: http://www.muzeum-stargard.pl.

\footnotetext{
2 (pol.) basteja - the roundel, the firing position of the artillery; the construction form between a battery tower and a bastion.

${ }^{3}$ It was reconstructed thanks to the EU financial project as part of the IVA program (European Regional Development Fund).
} 


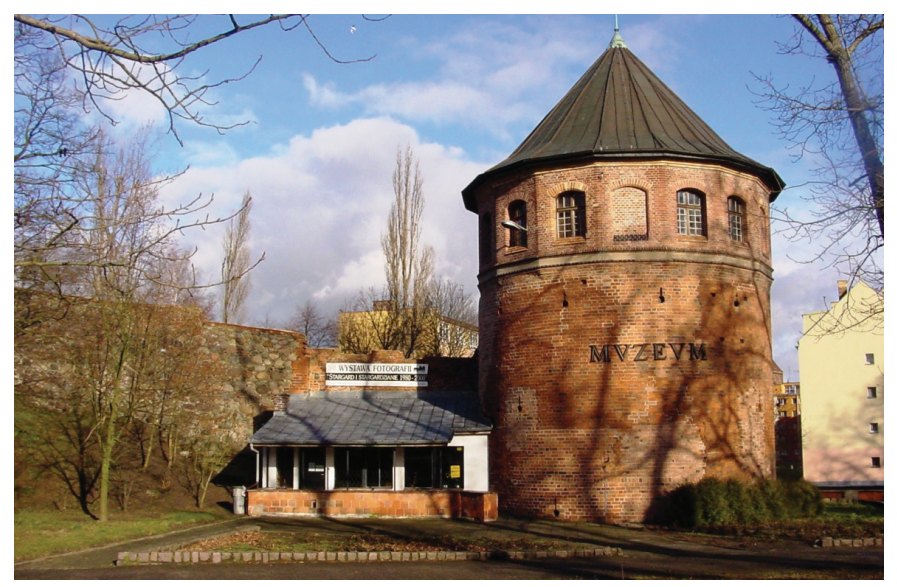

Photo 2. Basteja

Source: www.muzeum-stargard.pl.

\section{Educational services in Basteja}

The whole museum is composed by the educational and experimental area and the exhibition part spreading over four floors where the permanent exhibition presenting the history of Stargard from the mi-XIII century to the 20 's of the XX century is exposed (Photo 3). In the educational and experience area, there are museum classes, meetings and other events organized. The children can discover the job of an archeologist with mini-excavation where "treasures" like plates, coins and other secret objects to dig out are hidden.

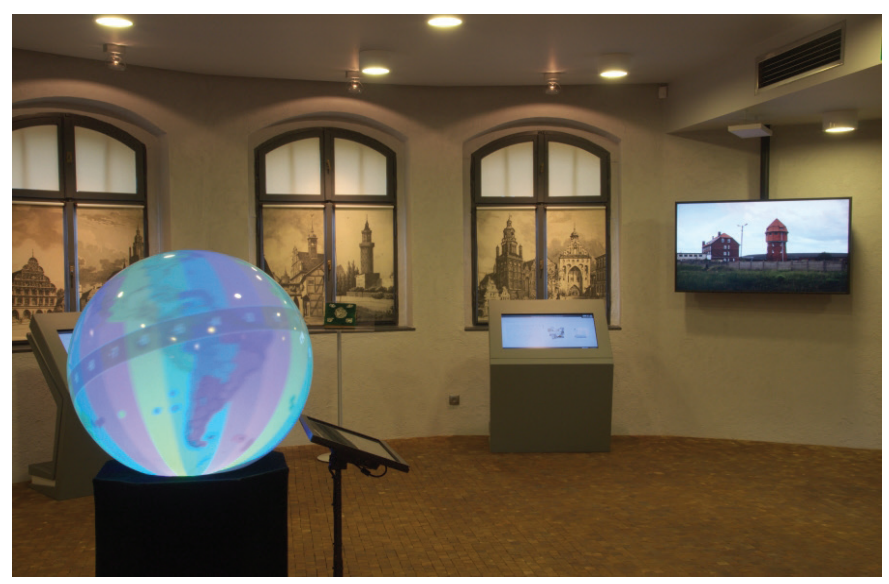

Photo 3. Exhibition inside Basteja

Source: www.muzeum-stargard.pl. 
The main target of the museum is education through classes and various events. Building identity with the local community and being creative are also important aims. All the subjects taught are adjusted to the age and interests and needs of young generation from kindergarten to high school. All activities are adapted for disabled children. There are traditional ex-cathedra classes with multimedia presentations and the ones where kids can learn while wandering through the permanent and occasional exhibitions. There are also periodical classes where children are invited to participate actively. The museum organizes also outdoor activities for children like municipal games and birthdays. It created even the first live escape room in town. The museum classes are offered for families, kindergartens and schools. For the last ones, they serve as complementary history and geography school classes. The subjects are presented in interactive way - discussions, multimedia presentations, meetings at exhibitions. One of the classes prepared is How much truth is in a legend? It's a multimedia presentation together with clay modelling courses. It's based on old legends and histories. The young participants get to know the monuments of Stargard and listen about the histories related to the town. When the weather permits, there is a walk along the fortifications.

Another class proposed is A key to Basteja. The youngsters learn about the history of Stargard visiting one of the permanent exhibitions (Photo 4). They participate in courses where they can try to write like it was in the past, touch the craftsman's products or feel like the knights of Stargard fortifications. After seeing the exhibition, they have tasks to complete in form of games on tablets. Every participant receives an educative mini-book entitled A Key to Basteja. This class is offered with elements of German language (edition, educational game, vocabulary related to Basteja). There are also classes offered with elements of English language. At first, the children visits the permanent exhibition and the other part is presented entirely in English. It's carried on as an educational game where the participants do exercises linked to the seen exhibition.

There is also class entitled folk events calendar. It's a multimedia presentation together with clay modelling courses concerning one of the subjects previously chosen. The children learn about time and space in folk tradition. They get to know the chosen holidays and their traditions like All Soul's Day, St. Catherine Day, St. Andrew Day, Christmas or Easter. They compare the Polish traditions with those from other countries and continents.

So close-so far is a set of courses where the young participants learn about the culture, national and ethnics minorities whichin the past had an impact on Stargard today (German, Jews and Ukrainians living in Stargard). When the weather permits, there are outdoor activities where children get to know the places where those minorities lived. During the courses, they learn new vocabulary, dances, games and listen histories about them. It's combined with clay modelling. There is also a music class proposed entitled Wake up your senses with elements of sensory art. Magic experimentation is another class to boost the children imagination. The youngest participants make different experiments. Seven-league boots where kids travel in time and space learning about culture. Within this class, the museum propose the topics : at the desert, following the Indians, Australian paths, at the poles, on the roof of the world. The participants learn about the exotic places and cultures-religions, traditions, art, habits and the everyday life of: African tribes, Australian Aborigines, Indians and others. The course sensibilise children to travel, to discover the world, to cultural diversity and the open spirit. The second part shows ways of travelling in the past (how, where and why people travelled). Children draw different exotic treasures from a merchant's chest. They build up their own mode of transport which would take them hundred years ago to everywhere they wanted. There are three projects to be chosen : choo-choo! (train), through seas and oceans (ship), through the sky (planes). 


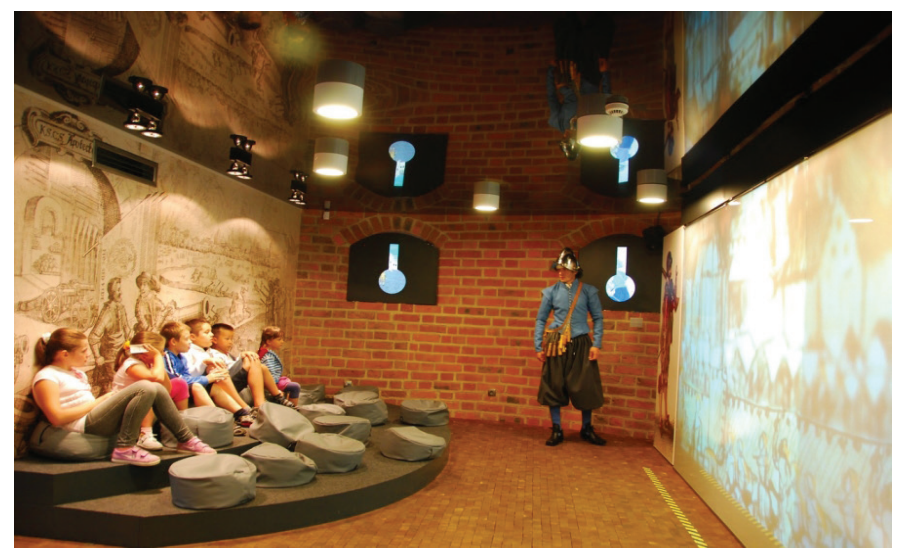

Photo 4. Basteja - the class for children

Source: www.muzeum-stargard.pl.

The museum institutions nowadays fit the institution model Market Repositioning Toward Entertainment. It means that the model used till now has changed because of the market of the cultural services where the museum offer is enlarged on the entertainment and elements of fun. At certain rate, it makes the museum institutions loose its serious nature. It requires additional skills from the employees., introduction of new substantive projects and adaptation of museum space for new activities (Rottermund, 2005, p. 17).

As part of the new model, Basteja museum organizes birthday parties for children between 5 to 12 years old. The birthday party in the museum is an interesting offer making virtue of necessity. Children disguised as pirates, travelers, princesses and knights are taken on a journey by the educators who transfer them to the past to discover how children used to spend their time. The children can also visit the royal court and learn about the royal etiquette as part of the museum offer entitled Birthday at royal court.

Other birthday proposition of the museum is Birthday of a young explorer where the children can discover the job of an archeologist- paleontologist. There is also a proposition (Un)forgettable games and fun where the youngsters can see what their parents, grand-parents and their ancestors were playing at.

At the birthday party On the pirate ship, the children try to find the treasure and be the masters of the oceans. The final proposition is Crazy laboratory - where the children make experiments, learning physics, astronomy and chemistry.

Amongst outdoor museum activities are municipal games like Detective in museum.

Children turn into explorers- detectives who spy out secrets of Basteja and the other museum building (close to Staromiejski Market). They search for treasures and solve puzzles. Children learn about the history of the town through plays and fun developing skills like creativity, observation and logic thinking.

The other museum attraction for Stargard is escape room, kind of a adventure game where the players are closed in a room and to leave it they have to solve puzzles and complete the tasks prepared (Photo 5). National Geographic classified it as one of seven best escape rooms ever (National Geographic Polska, 2018). 


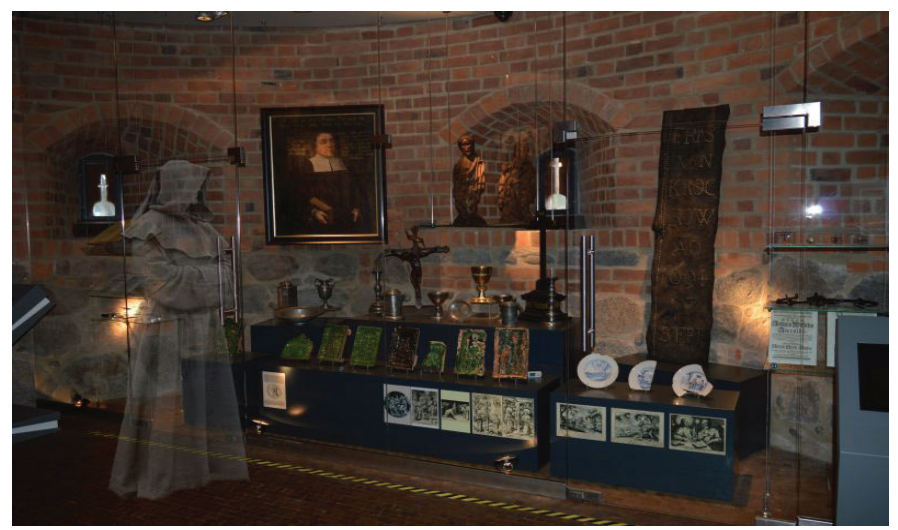

Photo 5. Escape room in Basteja

Source: www.muzeum-stargard.pl.

Another outdoor museum activity is annual historical feast organized for Stargard Days in Piastowski Park, close to Basteja. It's illustrating the example of Thirty Years' War (1618-1648). There are shows of reconstruction groups, the educational courses, the stands with handcrafts and food. The inhabitants learn about the history of the town. The last attraction taking part in Basteja is Night of Museums. The event is always linked to the occasional museum exhibition representing leitmotiv of the year.

\section{Conclusions}

Basteja, together with the Stargard historical and archeological museum is an excellent example of narrative museum designated for local community. The scientific and educational nature of the museum underlines the values of the local culture, habits and experience. Despite many challenges and problems that museums institutions have to face and all the hasty changes undergoing nowadays, they combine perfectly the model of traditional museum with the contemporary demands of the cultural service market presenting a varied range of educational offers especially for the youngest generation.

\section{References}

Historia muzealnictwa w Stargardzie (2018). Retrieved from: http://muzeum-stargard.pl/pl/o-muzeum/historia.

Kosiewski, P. (2015). W muzeach zmieniło się wszystko. Z prof. Małgorzatą Omilanowską, Minister Kultury i Dziedzictwa Narodowego rozmawia Piotr Kosiewski. Muzealnictwo, 56, 41-47.

Machałek, M. (2016). "Zanurzanie się" w przeszłość, czyli kilka uwag o edukacyjnych aspektach muzeów narracyjnych. Muzealnictwo, 57, 132-138.

Muzeum archeologiczno-historyczne Stargard (2018). Retrieved from: http://muzeum-stargard.pl/pl/edukacja.

National Geographic Polska (2018). 7 najbardziej niezwykłych escape roomów w Polsce. Retrieved from: www.national-geographic. $\mathrm{pl} /$ galeria/7-najbardziej-niezwyklych-escape-roomow-w-polsce/6-escape-room-basteja-stargard-muzeum-w-ktorym-nie-maczasu-n.

Rottermund, A. (2005). Nowy kształt instytucji muzealnej. Rocznik Lubuski, 31, 11-18.

StargardnaEuropejskim Szlaku Gotyku Ceglanego(2018). Retrievedfrom: https://www.stargard.pl/Europejski-Szlak-Gotyku-Ceglanego. 
Stecyk, A. (2016). Doskonalenie jakości usług edukacyjnych w szkolnictwie wyższym. Podejście metodyczne. Szczecin: Wydawnictwo Naukowe Uniwersytetu Szczecińskiego.

Ustawa z 29 czerwca 2007 r. o zmianie ustawy o muzeach, Dz.U. 2007, No. 136, item 956.

www.muzeum-stargard.pl.

Ziółkowska-Weiss, K. (2013). Ewolucja tradycyjnych funkcji muzeum w narracyjne muzea multimedialne na przykładzie muzeum Fabryka Emalia Oskara Schindlera. Przedsiębiorczość - Edukacja, 9, 162-174.

Cite this article aS: Dąbrosz-Drewnowska, P. (2018). Educational services in narrative museum taking as an example BASTEJA, the historical museum in Stargard. European Journal of Service Management, 4 (28/1), 61-69. DOI: 10.18276/ejsm.2018.28/1-08. 